生分解度に対してプロ ットした結果を Fig.

-3 に示す。

すなわち直鎖型では $\left(\mathrm{H}_{\mathrm{CH}_{3}}-6\right) /(\Sigma \mathrm{H}-5)$ の值が $3 \%$ 以下であり, 生分解度はほぼ $90 \%$ 以上を示すが，分枝型 では $\left(\mathrm{H}_{\mathrm{CH}_{3}}-6\right) /(\mathrm{NH}$ -5)の值は約 $23 \%$ 以 上であり生分解度は約 17\% 以下に低下する。 また直鎖型と分枝型と の混合アルキルベンゼ ンの $\left(\mathrm{H}_{\mathrm{CH}_{3}}-6\right) /(\Sigma \mathrm{H}$

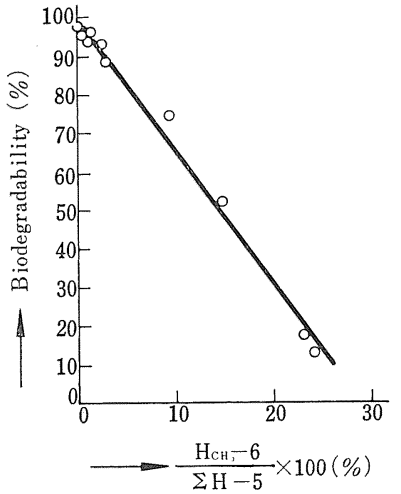

Fig. -3 Correlation between chain branching and biodegradability. I .
-5）の值と生分解性との関係は直鎖型と分枝型とを結 んだ直線上に乗り，直鎖，分枝，混合系を通じて分枝度 を表わす $\left(\mathrm{H}_{\mathrm{CH}_{3}}-6\right) /(\Sigma \mathrm{H}-5)$ と生分解性との閒には 直線関係があることがわかる。

しかしながら直鎖型と分枝型との混合物についてはガ スクロマト分析において直鎖型の 2-フェニル 異性体の ピークが分枝型アルキルベンゼンのピークと重なるので 混合系に㧍ける直鎖型アルキルベンゼンの 2-フェニル 異性体の含量を正確に求めることはできない。したがっ て 2-フェニル異性体含量をもとにして求めた $\left(\mathrm{H}_{\mathrm{CH}_{3}}\right.$ 6)/( $(\mathrm{H}-5)$ をパラメーターとする Fig.-3 に示した ような方法では混合系の生分解性を予測することはでき ない。

しかしながら $\left(\mathrm{H}_{\mathrm{CH}_{3}}-6\right) /(\Sigma \mathrm{H}-5)$ の代わりに $\mathrm{H}_{\omega}$ ! $(\Sigma \mathrm{H}-5)$ を用いるならば，ガスクロマト分析を行なう ことなく NMR のデータのみで枝分れの度合を表現す ることができる。 $H_{\omega}$ を枝分れのパラメーターに用いる ことは $\beta-\mathrm{CH}_{3}$ を除外して考えることになるので必ずし
も適切ではないが，分枝型から直鎖型というような広い 範囲にわたって考慮する場合には直鎖型における $\beta-$ $\mathrm{CH}_{3}$ はあまり考慮しなくてもよいように思われる。 この考えに従って $\mathrm{H}_{\omega} /(\Sigma \mathrm{H}-5)$ と生分解性との関係 を求めた結果が Fig.-4である。Fig.-3 に比べて直線

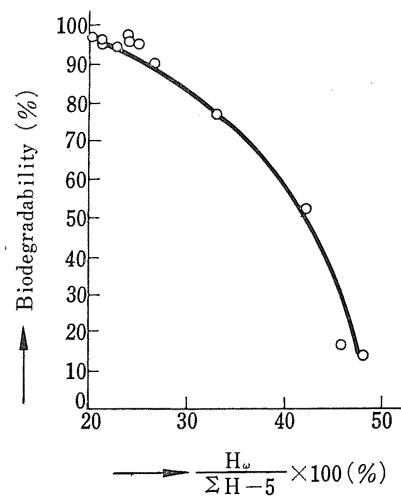

Fig. -4 Correlation between chain branching and biodegradability. II . 性は失われるが，生分 解性判定の目安には使 えると思われる。 現在生分解度の測定 には 2 週間といら長期 間を要しているが，

Fig。ー4を用いるなら ば短時間に生分解度の 予測が可能となるの で, 迅速性が要求され る製造または混合工程 管理などに適用できる と考えられる。

なお直鎖型アルキル ベンゼンスルホン酸塩 の生分解性にはアルキル基における枝分れメチル基の位 置ならびにアルキル基に結合しているフェニル基の位置 が影響を与えるので5)，本報告で述べたような枝分れの 数のみを考慮した方法は必ずしも厳密な方法ではない が，暫定簡易法として特色をなしているものと考えてい る。

(昭和 43 年 1 月 18 日受理)

\section{文献}

1）伊藤，下川，荒瀬，青村，工化，68，1441 (1965)

2) 井藤, 浜中, 山田, 小川, 工化, 70, 914 (1967)

3）小森, 大城, 油脂, 19,90 (1966)

4) T.H. Liddicoet, S.A. Olund, J. Am. Oil Chemists' Soc., 40, 5 (1963)

5) R.R. Durand, Chimie et Industrie, 94 (4), 345 (1965)

\title{
ラウリルサルコシネートータンパク質 複合体の血清学的研究
}

\author{
五島 黎子*。原 一 郎** \\ * ライオン歯磨株式会社研究所 (東京都墨田区本所) \\ ** 東京医科歯科大学教養部 (千葉県市川市国府台)
}

\section{Serological Studies on Lauryl Sarcosinate-Protein Complexes}

Reiko GojImA* and Ichirō HaRA**

* The Lion Dentifrice Co., LTD. (Honjyō, Sumida-ku, Tokyo)

** Tokyo Medical and Dental University (Kōnodai, Ichikawa-shi, Chiba-ken)

Lauryl sarcosinate (L)-egg albumin (EA)-and lauryl sarcosinate-bovine serum albumin (BSA) complexes $(\mathrm{EL}, \mathrm{BL})$ were prepared by mixing each component dissolved in water at $\mathrm{pH} 7.0 \sim 7.5$, 
respectively. Each complex comprising $10 \mathrm{mg}$ of protein in the ratio $\mathrm{L} /$ protein $=3$ was twice injected in rabbits with Freund's Adjuvant method followed by thrice subcutaneous injections with $1 \mathrm{mg}$ of each complex comprising $1 \mathrm{mg}$ of protein in the ratio of $\mathrm{L} /$ protein $=3$, respectively.

According to the ordinary precipitin reaction, we found only 1 or 2 positive reactions both in EAanti EL-and BSA-anti BL systems against 3 or 4 positive reactions in EA-anti EA-and BSA-anti BSA systems. On the other hand, we found only 1 positive reactions in the cases of EL-anti-EL-and BL-anti BL systems, respectively. The titers of antibody were $1: 1$ or $1: 4$ in EA-anti EL-against $1: 64$ or $1: 128$ in that of EA-anti EA systems, and $1: 4$ or $1: 8$ in BSA-anti BL-against $1: 32$ in BSA-anti BSA systems.

Arthus phenomenon showed moderate reaction for BSA-anti BL-and severe reaction (necrose) in BSA-anti BSA systems.

\section{1 緒言}

界面活性剂とタンパク質との相互作用については，種 々の研究が発表され, 最近さらに詳しい化学量論的扱い

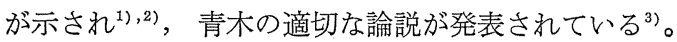
著者らはアルキルベンゼンスルホネート (ABS) と卵白 アルブミン (EA) およびシシ血清アルブミン (BSA) との複合体を作りその電気泳動の挙動および免疫化学的 な性状を調べだ。

界面活性剤の生物体に対する影響については, いくつ かの重要な問題があり,これらは富山の総説に詳し い5)。これらの影響の中でアレルギーについては不明な 点が多いが，著者らは前出の報告に预いて，ABS-EA， または ABS-BSA 複合体を Adjuvant 法といら免疫方 法によって家卜（鬼）に免疫したが，少なくとも普通の 方法によっては ABS あるいは ABS-タンパク質複合体 の抗体を検出することができず，そのかぎりにおいて抗 原一抗体反応による傷害は起こり得ないと結論した。元 来，毒性などその影響をみるとき単に経口的に与えるの みでなく，非経口的な投与についても考慮する必要があ るが，この実験仙いて，Adjuvant 法で免疫操作を行 なっても，なんら生体が影響を受けることがなく，他方 $\mathrm{ABS}$ の抗体の産生をみなかったことは最も一般的な実 験方法による結果である点に意味がある。以上の実験で は，ABS に対する抗体が得られないばかりか，通常で は抗体を産生しやすい EA あるいは BSA に対する抗 体の産生までが抑制されてしまった。

今回は実用上も粘膜などに影響があると考えられるラ ウリルサルコシネート (L) について実験を行ない，Lタンパク質複合体を作りこれを用いて Adjuvant 法に よって家トを免疫した結果について報告する。

\section{2 実験}

EA は硫安法で精製し, 凍結乾燥したもので口紙電気 泳動でスポット 1 個のものである。BSA はアーマー社 の製品を脱脂せずそのまま用いた。界面活性剤としては L の溶液型のものを使用した。L-アルブミン複合体の
生成はだいたい $\mathrm{pH} 7.0$ 7.5 の範囲において両者混合

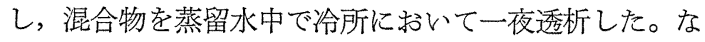
お L は $2 \%(\mathrm{wt} / \mathrm{vol})$ 溶液として用い, L : アルブミン $=3: 1$ および $1: 1$ 亿なるようにアルブミンを加えた。 L/アルブミン=3 および 1 のものを $\mathrm{EL}_{3}, \mathrm{EL}_{1}$ あるい は $\mathrm{BL}_{3}$ および $\mathrm{BL}_{1}$ とした。なお免疫には $\mathrm{EL}_{3}$ およ び $\mathrm{BL}_{3}$ を用いた。

免疫は $2 \sim 3 \mathrm{~kg}$ のウサギを用い，免疫方法は Freund のAdjuvant法により,これらの複合体のエマルション を, タンパク質として $10 \mathrm{mg}$ 相当を背面に注射した。 第 1 回免疫後 2 週間たってふたたび同量のエマルション を注射した。第 2 回注射後 25 日たって, タンパク質 $1 \mathrm{mg}$ に相当する複合体の水溶液を皮下に追加免疫した。 追加免疫は 3 日おきに 3 回行なった。対照として EA および BSA のみの免疫も行なった。

血清学的反応 ${ }^{6)}$ は普通の沈降反応重層法注1)を用い，㧧 原減量法注2)の場合は生理食塩水で抗原を希釈し，また 抗体減量法注3)の場合には 1.5\% のアラビアゴムの生理 食塩水溶液で希釈した。反応は常温で行ない，1〜2 hr 後に観察した。また寒天内沈降反応としては Ouchterlony 法注4) 用い，寒天（アガール J, 三光純薬製）の $1.5 \%$ 生理食塩水ゲルを作り, その中でゆっくりと $37^{\circ}$ C で抗原と抗体を反応させ，3５日後に観察した。

電気泳動はベロナール緩衝液 $(\mathrm{pH} 8.6, \mu 0.07)$ の溶 液でセルロースアセテート膜上で行ない， $0.5 \mathrm{~mA} / \mathrm{cm}$ の電流で $20 \sim 25 \mathrm{~min}$ 泳動させ，終了後ポンソー $3 \mathrm{R}$ の

注 1）細い試験管内で，抗血清の上に抗原穵静かに重ね，両 層の界面に抗原一抗体複合体学形成させ，その反応物 の量により，抗原，あるいは抗体の強さ（抗体の量） 它知る。

注 2）抗血清量を一定にし，抗原を系統的に希釈し，その反 忘の限度をみる。

注 3）抗原量它一定にし，抗血清の方定系統的に希釈し，そ の区応の限界を久る。抗体の量が多いほどその限界の 希釈度は大きくなる。

注 4）免疫泳動法とは，一般に抗原寒天ゲル内などで左右 の方向に泳動させ，その後上下の方向加ら抗体を拡散 させ抗原と抗体它ゆっくり反応させ，抗原物質の有効 成分の探索とか分画に用いる。 
$0.4 \%$ 水酶酸溶液で染色し, 脱色は $3 \%$ 酶酸溶液党用 いた。な拈免疫電気泳動注4) は寒天グルによる Grabar 法を行ない，1.5\% のアガール J のベロナール緩衝液 のゲルを用い L-タンパク質複合体を $0.6 \mathrm{~mA} / \mathrm{cm}$ で 2 〜 hr 泳動させてから抗血清を加えて反応させ $2 \sim 4$ 日後に観察した。

アルチュス (Arthus) 現象注5)は常法によって行ない， BSA および $\mathrm{BL}_{3}$ で家卜を Adjuvant 法によって免疫 し，約 4 週間後に，その家トの背面に BSA の生理食塩 水溶液に溶加して $0.25,0.5$ 抒よび $1 \mathrm{mg}$ を皮内に注 射し， 24 および $72 \mathrm{hr}$ 後にその注射部位の皮膚の変化 连観察した。

\section{3 結㖦}

\section{$3 \cdot 1$ 複合体の生成とその性状}

複合体の生成はすべて蒸留水中で行ならが, 透析も蒸 留水に対して行なった。こ扎らの複合体のセルロースア セテート膜上での電気泳動図は Fig.-1 に示す。

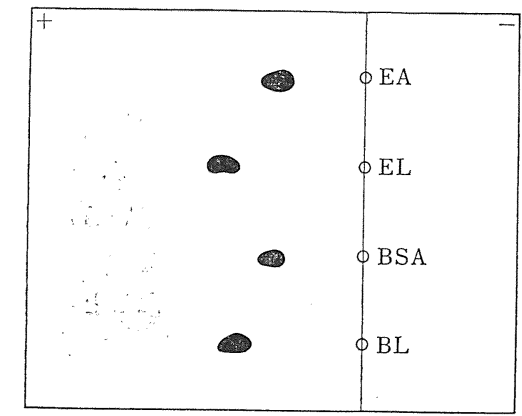

Fig.-1 Electrophoresis pattern of L-BSA and L-EA complexes on cellulose acetate paper.

Fig.-1 に示すように複合体の移動度はアルブミン単 体よりも大きい。また複合体 $\mathrm{EL}_{1}, \mathrm{EL}_{3}$ および $\mathrm{BL}_{1}$, $\mathrm{BL}_{3}$ を寒天ゲル内で泳動させ抗 $\mathrm{EA}$ 血清ならびに抗 BSA 血清と反応を行なった Grabar 法の結果は Fig.-2 炕示す。

Fig.-2 によるとやはり複合体がより速く移動してい ることがわかる。な抒 Fig.-2 中にはアルブミンに関す る単一の沈降線しか見られていない。ここにおいて，前 記のセルロースアセテート膜電気泳動図に押いて, 複合 体も鮮明なタンパク質染色を示して扤り，界面活性剤と 複合体をなしているタンパク質部分には，少なくともポ ンソー $3 \mathrm{R}$ と反応し染色される部分あるいは形がその

注 5）Arthus 現象はウサギに抗原を注射し，充分に抗体が 産生された時期に，その対応する抗原を皮内に入れる と定型的な 場合には注射後 $2 \sim 4 \mathrm{hr}$ で注射部位に水 シュ，壤死が現われ，24hr で最高になる反応で，免 疫学的特異性穵良く示し, その反応の強さは流血中の 抗体の量に比例する。
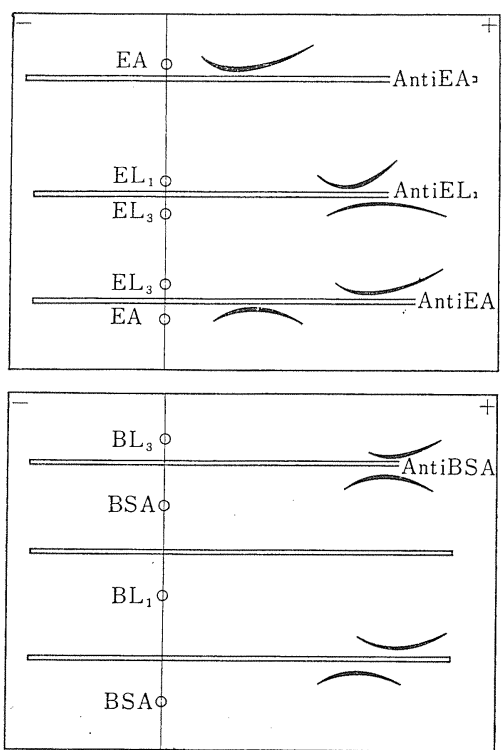

Fig.-2 Immunoelectrophoresis of L-protein complexes.

まま残っていると考えられる。

\section{$3 \cdot 2$ 血清学的反応}

複合体 $\mathrm{EL}_{3}$ で免疫した抗血清を抗 EL-1, 抗 EL-2, …としし，をた $\mathrm{BL}_{3}$ によるむのを抗 $\mathrm{BL}-1$, 抗 $\mathrm{BL}-2$, …, とした。抗血清は原液を, 抗原は生理食塩水で希䆏 して用いた。また抗 $\mathrm{EA}$ 系の抗血清と抗原との反応值 を Table-1 に示す。また抗 BSA 系の抗血清との反応 值を Table-2 に示す。

Table-1 Precipitin reaction between EA and anti L-EA serum.

\begin{tabular}{|c|c|c|c|c|c|c|c|}
\hline \multirow{3}{*}{$\begin{array}{l}\text { Antigen } \\
\text { Anti } \\
\text { serum }\end{array}$} & \multicolumn{3}{|c|}{ EA } & \multirow{3}{*}{\begin{tabular}{c}
$\begin{array}{c}\text { L-EA } \\
\text { complex }\end{array}$ \\
\multicolumn{2}{c}{ EL $_{3}$} \\
EA 0.02 \\
L 0.06
\end{tabular}} & \multicolumn{2}{|c|}{$\mathrm{BSA}$} & \multirow{2}{*}{$\begin{array}{c}\begin{array}{c}\mathrm{L}-\mathrm{BSA} \\
\text { complex }\end{array} \\
\mathrm{BL}_{3}\end{array}$} \\
\hline & & & & & & & \\
\hline & 0 & 0.1 & 0.2 & & 0.02 & 0.1 & $\begin{array}{ll}\mathrm{BSA} & 0.02 \\
\mathrm{~L} & 0.06 \\
\end{array}$ \\
\hline Anti EA & 3 & 2 & 3 & 1 & 0 & 0 & 0 \\
\hline Anti EL-1 & 2 & 3 & 3 & 1 & 0 & 0 & 0 \\
\hline Anti EL-2 & 2 & 2 & 3 & 1 & 0 & 0 & 0 \\
\hline Anti EL-3 & 1 & 1 & 2 & 1 & 0 & 0 & 0 \\
\hline Anti EL-4 & 1 & 1 & 1 & 1 & 0 & 0 & 0 \\
\hline Anti EL-5 & 1 & 1 & 0 & 1 & 0 & 0 & 0 \\
\hline$N-1^{*}$ & 0 & 0 & 0 & 0 & 0 & 0 & 0 \\
\hline $\mathrm{N}-2^{*}$ & 0 & 0 & 0 & 0 & 0 & 0 & 0 \\
\hline
\end{tabular}

*Control (intact rabbit serum)

Table-1 および Table-2 に示すように，EA-抗 EL 系の反忘は EA-抗 EA 系の反応に比較して弱くなって おり,また試験抗原に EL を用いた場合は, 単独の EA 抗原を用いた場合に比較して明らかな反応の低下がみら れている。BSA に関する Table-2 からもまったく同 様の傾向がみられる。さらに抗 EL 抗体に対して, BSA-L (BL) が，また抗 BL 抗体に対して EA-L(EL) 
Table-2 Preciptin reaction between BSA and anti L-BSA serum.

\begin{tabular}{|c|c|c|c|c|c|c|}
\hline \multirow{3}{*}{$\begin{array}{l}\text { Anti- } \\
\text { Anti } \\
\text { serum }\end{array}$} & \multicolumn{3}{|c|}{ BSA } & \multirow{2}{*}{\begin{tabular}{|c|}
$\begin{array}{c}\mathrm{L}-\mathrm{BSA} \\
\text { complex }\end{array}$ \\
$\mathrm{BL}_{3}$
\end{tabular}} & \multirow{3}{*}{$\frac{\mathrm{EA}}{0.02}$} & \multirow{3}{*}{ 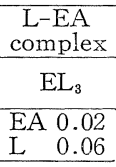 } \\
\hline & \multirow[b]{2}{*}{0.02} & \multirow[b]{2}{*}{0.1} & \multirow[b]{2}{*}{0.2} & & & \\
\hline & & & & $\begin{array}{ll}\mathrm{BSA} & 0.02 \\
\mathrm{~L} & 0.06\end{array}$ & & \\
\hline Anti BSA-1 & 3 & 3 & 3 & 2 & 0 & 0 \\
\hline Anti BSA-2 & 3 & 3 & 3 & 2 & 0 & 0 \\
\hline Anti BL-1 & 3 & 2 & 2 & 2 & 0 & 0 \\
\hline Anti BL-2 & 1 & 1 & 1 & 1 & 0 & 0 \\
\hline Anti BL-3 & 1 & 1 & 1 & 1 & 0 & 0 \\
\hline Anti BL-4 & 0 & 0 & 0 & 0 & 3 & 1 \\
\hline $\mathrm{N}-1^{*}$ & 0 & 0 & 0 & 0 & 0 & 0 \\
\hline $\mathrm{N}-2^{*}$ & 0 & 0 & 0 & 0 & 0 & 0 \\
\hline
\end{tabular}

* Control (intact rabbit serum)

が沈降反応を示していないことから，Lそのものに対す る抗体泣明されない。つぎに同じ反応を抗体隇量法で 行なった結果を Table-3，4 亿示す。抗血清はアラビ アゴムの $1.5 \%$ 生理食塩水溶液で希釈し, 抗原は $\mathrm{EA}$, BSA の $0.02 \%$ 生理食塩水溶液を用いた。

Table-3 招よび Table-4 によると, EA と抗 EA と の反応が 1:64 まではっきりと認めら机に比較して, $\mathrm{EA}$ と抗 $\mathrm{EL}$ の反応はたかだか $1: 8$ 以下であって, EL -3 および EL-4 においては 1:1 がやっとであり, 少
Table-3 Precipitin reaction between EA and anti EL serum (antibody dilution method) (EA, 0.02\%).

\begin{tabular}{l|c|c|c|c|c|c|c|c|c|c|c}
\hline $\begin{array}{c}\text { Anti serum } \\
\text { dilution }\end{array}$ & $1: 1$ & $1: 2$ & $1: 4$ & $1: 8$ & $1: 16$ & $1: 32$ & $1: 64$ & $1: 128$ & $1: 256$ & $1: 512$ \\
Anti serum & & & & & & & & & & \\
\hline Anti EA & 3 & 3 & 2 & 2 & 2 & 1 & 1 & 0 & 0 & 0 \\
Anti EL-1 & 2 & 1 & 1 & 1 & 0 & 0 & 0 & 0 & 0 & 0 \\
Anti EL-2 & 1 & 1 & 1 & 0 & 0 & 0 & 0 & 0 & 0 & 0 \\
Anti EL-3 & 1 & 0 & 0 & 0 & 0 & 0 & 0 & 0 & 0 & 0 \\
Anti EL-4 & 1 & 0 & 0 & 0 & 0 & 0 & 0 & 0 & 0 & 0 \\
\hline
\end{tabular}

Table-4 Precipitin reaction between BSA and anti BL serum (antibody dilution method)(BSA, 0.02\%).

\begin{tabular}{l|c|c|c|c|c|c|c|c|c|c}
\hline $\begin{array}{c}\text { Anti serum } \\
\text { dijution }\end{array}$ & $1: 1$ & $1: 2$ & $1: 4$ & $1: 8$ & $1: 16$ & $1: 32$ & $1: 64$ & $1: 128$ & $1: 256$ & $1: 512$ \\
Anti serum & & & & & & & & & \\
\hline Anti BSA-1 & 3 & 2 & 2 & 1 & 1 & 1 & 0 & 0 & 0 & 0 \\
Anti BSA-2 & 3 & 2 & 2 & 1 & 1 & 0 & 0 & 0 & 0 & 0 \\
Anti BL-1 & 1 & 1 & 0 & 0 & 0 & 0 & 0 & 0 & 0 & 0 \\
Anti BL-2 & 1 & 1 & 1 & 0 & 0 & 0 & 0 & 0 & 0 & 0 \\
Anti BL-3 & 1 & 1 & 1 & 0 & 0 & 0 & 0 & 0 & 0 & 0 \\
\hline
\end{tabular}

なくとも L-EA 複合体を抗原として用いた場合抗 EA 抗体の産生が非常に抑制されていることがわかる。をた BSA 系でもだいたい同じ傾向があり，BSA と抗 BSA の反応が 1:32 あるいは 1:16 までみられるが，BLと 抗 BSA との反応は 1:4 以下であって, これも複合 a)

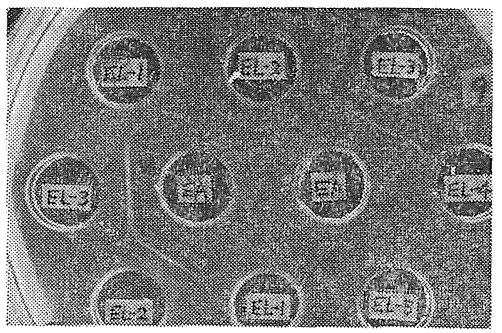

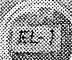

b)
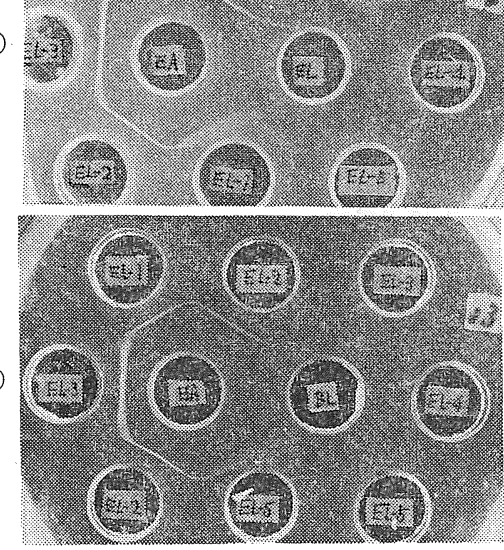

Fig-3 Precipitin reaction in agar gel by Ouchterlony method (EA system).
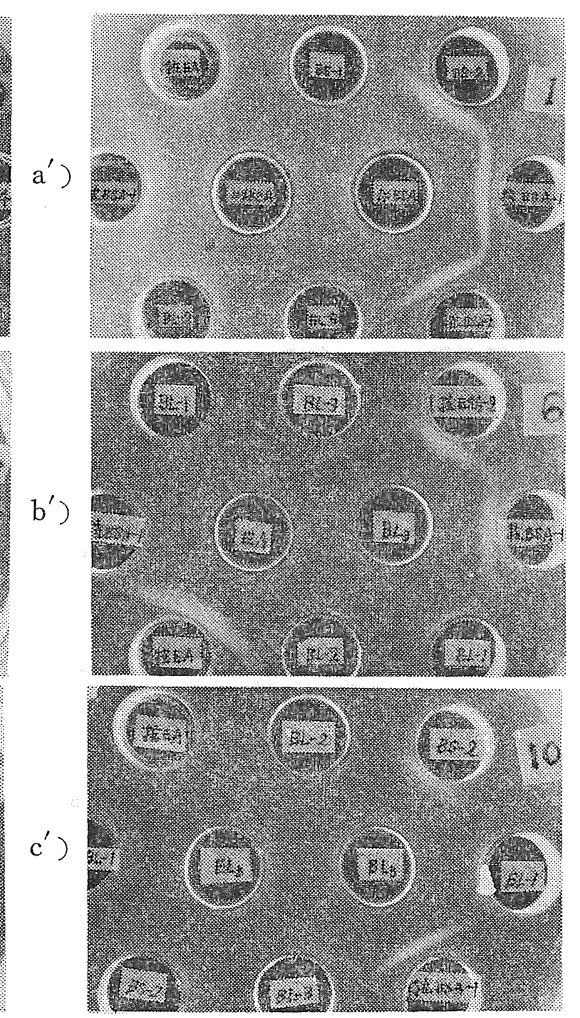

Fig.-4 Precipitin reaction in agar gel by Ouchterlony method(BSA system).

体を用いると抗 BSA 抗 体の産生が明らかに抑制 されたことを示してい る。

なお, Ouchterlony 法 の結果は Fig。-3,4 に示 す。Fig.-3 (a) に拉いて $\mathrm{EL}-1 \sim \mathrm{EL}-5$ (EL-4 を 除く)の沈降帯瀜合 し，Fig.-3(c) において $\mathrm{BL}$ と抗 $\mathrm{EL}$ 系との反応 がみられていないのは Table-1の結果とも一致 している。ただし Fig. -3 (b) において, 抗原 $\mathrm{EA}$ と抗原 $\mathrm{EL}$ との反応 は完全に一致はしていな い。EA と抗 $\mathrm{EL}-2, \mathrm{EL}$ と抗 EL-2 とは一部融合 し，一部は突起 (spur) になっておりこれはしに よる $\mathrm{EA} の$ 抗原性の一 部が変化したことを示し ているがまったく異質の ものを呈したといら訳で 
はない。この点, 原》 は界面活性剤による $\beta$ ーリポタン パク質の抗原性の変化を報告しているが，これらの変化 がごういら分子上での変化であるかは今後の検討を必要 とする。BSA 系については，Fig.-4 に示されている が，10\% BSA を用いると抗原過剰となって反応がみら れず，1\% BSA のときに抗 BS，抗 BSA および抗 BL との沈降帯が融合している。また BL を抗原とし て用いた場合，抗 BSA との反応の方が抗 $\mathrm{BL}$ との反 応よりはるかに強く出現しているがこれも Table-2 の結果と一致している。ただし BSA の場合界面活性剤 による BSA の抗原性の一部変化は認められなかった。

さらに BSA 系のウサギについてのみ Arthus 現象を 調べたがその成績はつぎに示すとおりであった。

Table-5 Arthus phenomena by laurylsarcosinateBSA complex.

\begin{tabular}{|c|c|c|c|}
\hline & $\begin{array}{l}\text { Intensiti } \\
\text { after } 241\end{array}$ & $\begin{array}{l}\text { es Intensities } \\
\text { ar after } 72 \mathrm{hr}\end{array}$ & Observations \\
\hline $\begin{array}{l}\text { Rabbit immunized } \\
\text { with BSA }\end{array}$ & 3 & 4 & $\begin{array}{l}\text { Erythema, Edema } \\
\text { Necrosis }\end{array}$ \\
\hline $\begin{array}{l}\text { Rabbit immunized } \\
\text { with } \mathrm{BL}\end{array}$ & 2 & 0 & $\begin{array}{l}\text { Erythema } \rightarrow \\
\text { Normal }\end{array}$ \\
\hline Rabbit control & 0 & 0 & Normal \\
\hline
\end{tabular}

Table-5 に示すように BSA のみで免疫したウサギ の反応はひどく, BSA と L の複合体で免疫したウサ ギのそれは弱くなっている。Arthus 現象の強度は一般 にそれが有する抗体，抗体価に比例するといわれてお り,この点からも BL を用いると抗 BSA 抗体の産生 能力が落ちることを示している。

\section{3 考察}

$\mathrm{BSA}$ あるいは EA のよらなアルブミン類が炭化水 素 $^{8)}$, アルコール類 ${ }^{8)}$, また脂肪酸イオンなどと結合す ることは良く知られている9。一方 BSA や EA と界 面活性剂とも良く結合し, これらの化学量論的取扱いも 行なわれている12,2)。Foster によると BSA(A とする) と $\mathrm{ABS}\left(\mathrm{D}\right.$ とする) との複合体は, $\mathrm{pH} 6.0$ で $\mathrm{AD}_{m}$, $\mathrm{AD}_{n}, \mathrm{AD}_{2 n}$ と 3 種が生成し， $m=11, m=38$ であるが， $\mathrm{pH} 9.5$ 以上では $\mathrm{AD}_{n}$ は消失してしまうという。それ ぞれの移動度は $1.01,1.16,1.97 \mathrm{~cm}^{-2} \mathrm{~V}^{-1} \mathrm{sec}^{-1} \times 10^{4}$ である。また青木も EA と ABS の結合を良く研究し ているが31,10), ABS/EA が 320 といら大きな複合体も 得られている。しかしながら，本論文に用いた Lのよ らなカルボン酸になったものについては詳しく知られて いない。しかし Fig.-1 と 2 からもわかるように移動 度も大きくなっていることから結合物が生成していると 考えられ，ABS の場合の類推からL/アルブミンがかな り大きいものではないかと考えているが，ABS の場合 と異なってL-アルブミンの結合力はわずか弱いものと 考えられるので, 複合体の組成などについては今後の検
討に待たなくてはならない。これらの複合体， $\mathrm{BL}$ およ び ELを用いて免疫を行なったときの抗原性についてみ ると,これはまったく前報の ABS の場合と同じ傾向を 有し, Table-1, 2にみるように抗原減量法で力価が低下 していることがわかるし，一方 Table-3および Table-4 に示すように抗体減量法によっても抗体価が やや低くなっており, 複合体の免疫原性の低いことがわ かる。タンパク質の化学修飾による抗原性の劣化あるい は質的変化については, Mourer ら ${ }^{11)}$ が BSA, EA に ついて詳細にみている成，それによると，脱アミノある いはアセチル化などで $\mathrm{NH}_{3}{ }^{+}$基を $60 \%$ 化学修飾すると 修飾 BSA の抗 BSA 抗体に対する反応が $66 \%$ 弱く なり，一方化学修飾した BSA に対する抗体 (抗修飾 $\mathrm{BSA}$ 抗体）と BSA との反応は $28 \%$ に減少する。こ のようにアミノ基が免疫抗体に対しても, 抗原一抗体反 応に沶ける抗原の反応性に対しても強い影響を及ぼして いることがわかる。このように化学修飾による抗原性の 変化は, $\beta$ リ リ゚タンパク質に拉いて, アセチル化, アル サニル化を行ならときも観察されており，この場合は夕 ンパク質の conformation の変化も考えられている 12),13)。本研究の場合, 本来 $\mathrm{EA}$ および BSA が有して いるウサギに対する強い免疫原性がかなり弱められてい ることは，L による構造の変化も否定できないが ${ }^{14)}$, 電気泳動のパターンから，これらの複合体においてマイ ナスの電荷の增大が移動度の上昇の一原因と考えられる ことから，L によってアミノ基が拉おれてしまって いると考えるのが妥当のようである。このよらにアミノ 基あるいは，それに類した極性基の L によるしゃへい が，EA および BSA の免疫原性の劣化の主たる原因と 考えている。

なおこの場合に前報と同様，Freund の adjuvant を 用いた免疫を行なっているので，この操作が果たして， L-BSA のような複合体を抗原として用いるに際して適 当かどらか大いに疑問である。その理由として, adjuvant 中に多量の界面活性剤が含まれており，これと複合体中 の界面活性剤とがからみ合っているためにいるいろの変 化が起こる可能性もあるからである。事実野島らによる カルジオリピンーアルブミン複合体の免疫に抒いて, Adjuvant 法を用いてはぐあいが悪いと述べている ${ }^{15)} 。$ しかしこの場合もカルジオリピンの抗体を得るために不 適当であったのであって，アルブミンについては言及し ていない。

なお L に対する抗体は少なくとも今回用いた沈降反 応系の抗原一抗体反応において検出されず，このかぎり において界面活性剤の抗原性は認められない。しかしこ の場合も $-\mathrm{COOH}$ 基は結合に使われてふさがれている かも知れず - $\mathrm{COOH}$ 基を遊離の状態においたような場 合のことは不明である。概して, 界面活性剂の免疫化学 
は合成ポリペプチドを carrier として複合体を作って検 討する余地があると考えている。

\section{(昭和 42 年 11 月 28 日受理) 文献}

1) R.V. Decker, J.F. Foster, Biochemistry, 5, 1242 (1966)

2) R.V. Decker, J.F. Foster, J. Biol. Chem., 242, 1526 (1967)

3) 青木, 油化学, 17, 184 (1968)

4）原, 守島, アレルギー, 15, 864 (1966)

5) 富山, 油化学, 16, 138 (1967)

6) 鈴木“臨床検查技術講座 2 集, 血清学”’ (昭 40 年) 金原
7）原, 佐藤, 第 40 回日本生化学総会報告, 昭 42 年 11 月

8) A. Ray, J. Reynolds, H. Polet, J. Steinhardt, Biochemistry, 5, 2606 (1966)

9) D.S. Goodman, J. Am. Chem. Soc., 80, 3892 (1958)

10) K. Aoki, J. Am. Chem. Soc., 81, 1885 (1959)

11) P.H. Maurer, J.S. Ram, S. Ehrenpreis, Arch. Biochem. Biophys., 67, 1961 (1957)

12) S. Margolis, R.G. Langdon, J. Biol. Chem,, 241, 477 (1965)

13) R.S. Lees, J. Lipid Res., 8, 396 (1967)

14) J.A. Reynolds, S. Herbert, H. Polet, J. Steinhardt, Biochemistry, 6, 937 (1967)

15）野島, 奥山，第 40 回日本生化学総会報告，昭 42 年 11 月

\section{統計}

昭和 42 年塗料・印刷インキ生産量(単位： t) 昭和 42 年セッケン等生産実績(単位 $\mathrm{t},:$ 千円)

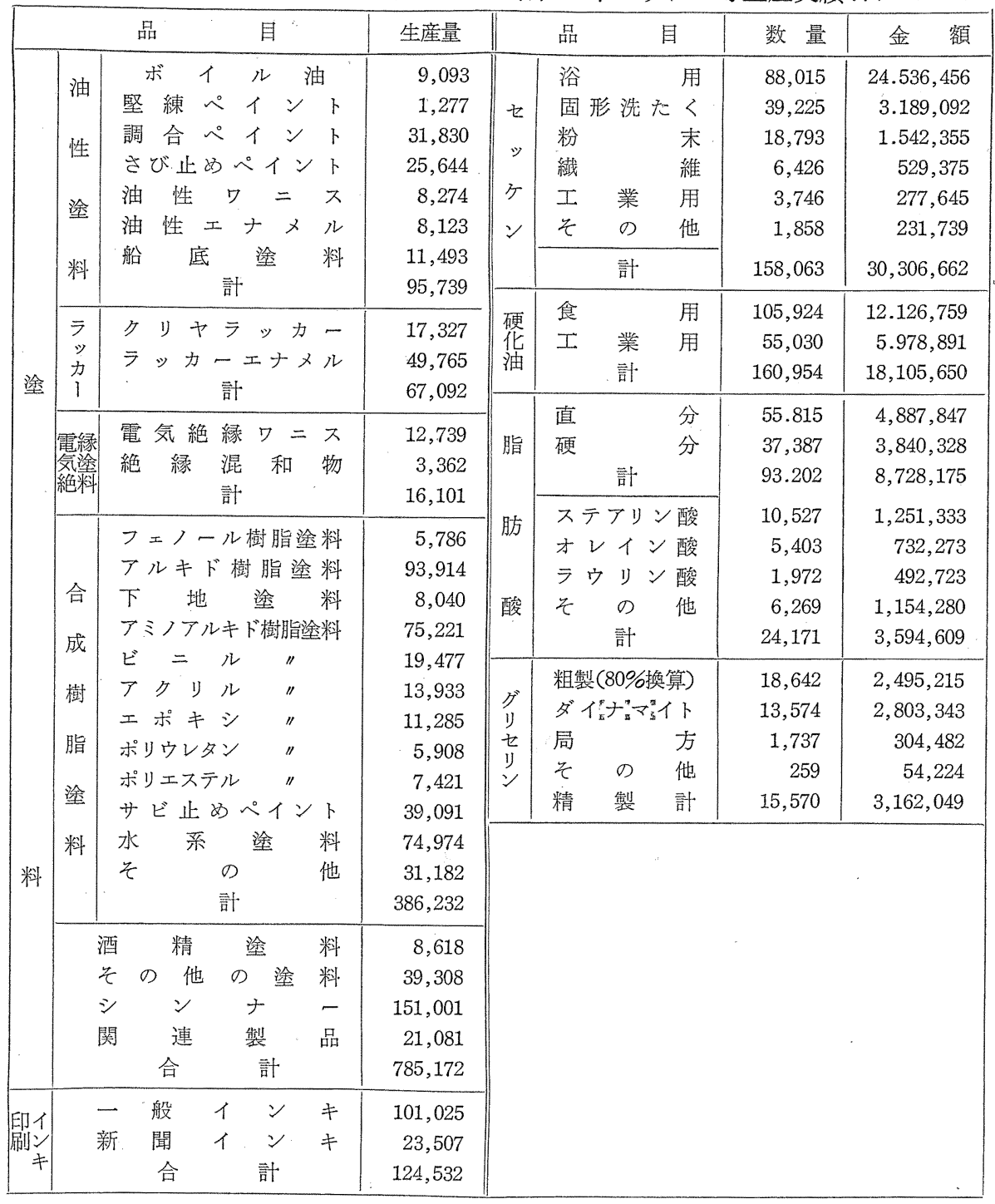

